\title{
Preface: Shallow lakes research: advances and perspectives
}

\section{The 9th International Shallow Lakes Conference}

\author{
S. Nandini · S. S. S. Sarma $\cdot$ Erik Jeppesen $\cdot$ Linda May
}

Received: 20 September 2018/Revised: 17 November 2018/Accepted: 24 November 2018/Published online: 19 December 2018 (C) Springer Nature Switzerland AG 2018

At the eighth Shallow Lakes meeting in Antalya (Turkey), a decision was made to hold the ninth meeting in Mexico. Preparations began with a visit by Brian Moss and Joyce Moss, in January 2015, who helped us choose the venue for the conference. But, sadly, Brian Moss passed away in 2016 and was unable to attend the meeting.

The ninth conference began with a celebration of Moss's life and research, presented by Erik Jeppesen. He provided an inspiring overview of Moss's amazing career, which spanned early phytoplankton studies in the African Lake Chilwa, a research stay in the US, the very famous broadland lake studies in East Anglia, nitrogen limitation studies in the West Midland Meres, and numerous experimental studies associated with major EU projects. All of his works resulted in many scientific publications, and numerous books and book

Guest editors: S. Nandini, S. S. S. Sarma, Erik Jeppesen \& Linda May / Shallow Lakes Research: Advances and Perspectives

S. Nandini $(\bowtie) \cdot$ S. S. S. Sarma

National Autonomous University of Mexico,

Tlalnepantla, Mexico

e-mail: nandini@unam.mx

E. Jeppesen

Aarhus University, Silkeborg, Denmark

L. May

Centre for Ecology \& Hydrology, Midlothian, UK chapters. Moss's last book (Moss, 2018) was published with editorial help from his wife, Joyce. In his presentation, Erik highlighted Moss's unique contributions as a scientist. These included his broad-scale holistic way of thinking; his unselfish and strong project leadership (taking the lead when needed but letting others develop their careers when not); his amazing achievements as a teacher and mentor (many of his former students are in scientific or management roles today); his important role as an eminent, inspiring and challenging speaker and writer; and, last but not least, his influential role as an exemplary human being. Several obituaries have highlighted the importance of Brian Moss; these include one previously published in Hydrobiologia in 2016 (Jeppesen \& Johnes, 2016).

We would like to dedicate these proceedings, which are based on presentations given at the IX International Shallow Lakes Conference, held under the auspices of SIL and the National Autonomous University of Mexico (UNAM), in Merida City (Mexico) during February 19-24, 2017, to the late Brian Moss, founder of the modern ideas/hypotheses on the ecological dynamics of shallow lakes. Moss was a friend and mentor to many of the participants of the meeting and a guiding light to other shallow lake researchers around the world.

The conference comprised almost 100 oral and poster presentations, and the proceedings contained 10 carefully selected articles. Since the early works of 
Table 1 International Shallow Lakes Conferences (SLC) and proceedings published, including serial number, year, venue, journal, number of articles published and guest editors (modified from Nandini \& Sarma, 2017)

\begin{tabular}{|c|c|c|c|c|c|}
\hline $\begin{array}{l}\text { SLC } \\
\text { no. }\end{array}$ & Year & Country & $\begin{array}{l}\text { Hydrobiologia vol. } \\
\text { and year }\end{array}$ & $\begin{array}{l}\text { No. of } \\
\text { articles }\end{array}$ & Editors \\
\hline 1 & 1992 & Denmark & 275-276, 1994 & 44 & E. Mortensen, E. Jeppesen \& M. Sondergaard \\
\hline 2 & 1995 & Poland & $342-343,1997$ & 44 & L. Kufel, A. Prejs \& J. I. Rybak \\
\hline 3 & 1998 & Germany & $408-409,1999$ & 43 & N. Walz \& B. Nixdorf \\
\hline 4 & 2002 & Hungary & $506-509,2003$ & 102 & $\begin{array}{l}\text { J. Padisák, L. G. Tóth, S. Herodek, S.C. Maberly, I. Tátrai \& L. } \\
\text { Vö }\end{array}$ \\
\hline 5 & 2005 & $\begin{array}{l}\text { The } \\
\text { Netherlands }\end{array}$ & 584,2007 & 41 & R. D. Gulati, E. Lammens, N. De Pauw \& E. Van Donk \\
\hline 6 & 2008 & Uruguay & 646,2010 & 26 & $\begin{array}{l}\text { M. Meerhoff, M. Beklioglu, R. Burks, F. García-Rodríguez, N. } \\
\text { Mazzeo \& B. Moss }\end{array}$ \\
\hline 7 & 2011 & China & 710,2013 & 22 & Z. Liu, B.P. Han \& R.D. Gulati \\
\hline 8 & 2014 & Turkey & 778,2016 & 19 & $\begin{array}{l}\text { M. Beklioglu, M. Meerhoff, T. A. Davidson, K. A. Ger, K. } \\
\text { E. Havens \& B. Moss }\end{array}$ \\
\hline 9 & 2017 & Mexico & 2019 & 10 & S. Nandini, S.S.S. Sarma, E. Jeppesen \& L. May \\
\hline
\end{tabular}

Hrbácek et al. (1961) and Brooks \& Dodson (1965), it has become evident that predation plays a key role in the trophic dynamics of lakes, not least those that are shallow, and that the role of predation is changing with climate, being stronger in warm climate zones (Moss et al., 2011; Meerhoff et al., 2012). With climate warming, we can therefore expect major changes in the role of predation. Three works in these proceedings are concerned with predation effects in shallow waterbodies in warmer climates. Sarma et al. (2019) studied the effect of cyclopoid copepod predation in hypertrophic waterbodies and included both field and laboratory data. They found that Acanthocyclops americanus (Marsh, 1893) feeds on phytoplankton (including cyanobacteria) and zooplankton (including rotifers, cladocerans, and naupliar stages of copepods). A majority of the prey items of these zooplankton were rotifers, mostly brachionids. The copepods were even able to consume evasive rotifers, such as Synchaeta pectinata Ehrenberg, 1832 and Polyarthra vulgaris Carlin, 1943. The cladoceran prey in the gut of Acanthocyclops were Alona rectangula Sars, 1862, Bosmina longirostris (O.F. Müller, 1785), Ceriodaphnia dubia Richard, 1894, Chydorus sphaericus (O.F. Müller, 1776), and Daphnia magna Straus, 1820. The role of macrophytes in predation is particularly understudied in warm climate zones. In an experimental study in Argentina, Mamani et al.
(2019) found that cladocerans preferred the vegetated zone, in the presence of fish and/or macroinvertebrate predation. Dantas et al. (2019) highlighted the important role of benthivorous and planktivorous fish on nutrient cycling in shallow lakes, with benthivorous and planktivorous fish leading to an increase in phytoplankton biomass although through different mechanisms.

Two papers consider the roles of different factors affecting phytoplankton biomass. That of cyanobacteria in warm shallow lakes was addressed by Havens et al. (2019) and González-Madina et al. (2019). Based on long-term data from a large lake in Florida that has been affected by climatic changes, Havens et al. (2019) developed a conceptual model to illustrate how blooms are regulated by high concentrations of nutrients, the absence of large zooplankton, and changes in climate, including rainfall. In addition, based on weekly sampling over two summer seasons at Laguna del Sauce, one of the main drinking water sources in Uruguay, González-Madina et al. (2019) showed that, when inorganic turbidity exceeds 30 NTU, phytoplankton biomass is reduced; they also demonstrated the important role of $\mathrm{N}: \mathrm{P}$ ratio in the development of cyanobacterial blooms.

Climate warming is expected to affect the hydrology of lakes substantially, with implications for water level and salinity (IPCC, 2007); such changes could 
have strong implications for shallow lake ecosystems (Coops et al., 2003, Jeppesen et al., 2015). Two contributions in the proceedings address the potentially important effect of hydrology on ecosystem interactions in shallow lakes. Mayer \& Pilson (2019) present information on the effects of water-level fluctuations on endemic waterbirds in Hawaii, with their results suggesting that these birds prefer to feed at low water levels because these help to concentrate fish and other prey, leading to an increase in feeding rates. Menezes et al. (2019) studied differences in food webs and trophic states of semi-arid and humid lakes that lie next to each other in the Natal region of Brazil, with a focus on evaporation ratios; they concluded that catchment area-to-lake area ratio, nutrient concentrations, and abundances of plankton and fish were higher in semiarid areas, whereas inlet water-to-evaporation ratio, water transparency, and macrophyte coverage were higher than those in humid areas. The results suggest that a reduction in inlet water-to-evaporation ratio, due to global warming, will increase lake eutrophication, which, in turn, as in temperate regions, will alter the trophic structure of the freshwater community.

In many developing countries, soil erosion has become a major environmental issue and more extreme weather in a future warmer climate may amplify the problem (McCarthy et al., 2001). Teffera et al. (2019) compared selected limnological variables from the two largest Rift Valley lakes in Ethiopia, and found that Lake Abaya was much more turbid and had lower plankton biomass than Lake Chamo, which could be explained by a major difference in sediment load. They concluded that conservation should focus on reducing sediment inflows to lakes from their catchments to prevent further deterioration of species richness in the lake.

Nowadays, many new methods and instrumental advancements are available that could help in the monitoring of lake environments at high frequency. Two contributions present novel methodological solutions to resolving some of the biological problems of shallow lakes. Sòria-Perpinyà et al. (2019) used remote sensing techniques to explore the evolution, duration, and intensity of the clear-water phase in a eutrophic waterbody (Albufera of Valencia, Spain) and concluded that rapid flushing could be used to remediate eutrophication in this waterbody. Chesney et al. (2019) used chlorophyll fluorescence to assess food selection by Daphnia magna in terms of green algae, diatoms, and cyanobacteria and concluded that gut transit time decreased when food contained cyanobacteria rather than green algae, alone.

The publication of these proceedings in Hydrobiologia maintains the tradition of recording selected presentations from the Shallow Lakes Conferences, thanks to the Editor in Chief, Prof. Koen Martens, the Associate Editor in Chief of the proceedings, Dr. Sidinei Thomaz, and the many reviewers who helped ensure the high quality of articles in 2018. As with previous Shallow Lakes Conferences (Table 1), the proceedings have been published online within 2 years of the end of the conference. The series of proceedings from these meetings document continuous advances in the field of shallow lakes research, and we hope that 2019 continues that tradition.

\section{References}

Brooks, J. L. \& S. I. Dodson, 1965. Predation, body size and composition of plankton. Science 150: 28-35.

Chesney, T., A. R. Sastri, B. E. Beisner, S. Nandini, S. S. S. Sarma \& P. Juneau, 2019. Application of fluorometry (Phyto-PAM) for assessing food selection by cladocerans. Hydrobiologia, this issue. https://doi.org/10.1007/s10750018-3753-2.

Coops, H., M. Beklioglu \& T. L. Crisman, 2003. The role of water-level fluctuations in shallow lake ecosystems: workshop conclusions. Hydrobiologia 506: 23-27.

Dantas, D. D. F., P. L. Rubim, F. A. de Oliveira, M. R. A. da Costa, C. G. B. de Moura, L. H. Teixeira \& J. L. Attayde, 2019. Effects of benthivorous and planktivorous fish on phosphorus cycling, phytoplankton biomass and water transparency of a tropical shallow lake. Hydrobiologia, this issue. https://doi.org/10.1007/s10750-018-3613-0.

González-Madina, L., J. P. Pacheco, L. Yema, P. de Tezanos, P. Levrini, J. Clemente, C. Crisci, J. J. Lagomarsino, G. Méndez, C. Fosalba, G. Goyenola \& N. Mazzeo, 2019. Drivers of cyanobacteria dominance, composition and nitrogen fixing behavior in a shallow lake with alternative regimes in time and space, Laguna del Sauce (Maldonado, Uruguay). Hydrobiologia, this issue. https://doi.org/10. 1007/s10750-018-3628-6.

Havens, K. E., G. Ji, J. R. Beaver, R. S. Fulton III \& C. E. Teacher, 2019. Dynamics of cyanobacteria blooms are linked to the hydrology of shallow Florida lakes and provide insight into possible impacts of climate change. Hydrobiologia, this issue. https://doi.org/10.1007/s10750017-3425-7.

Hrbáček, J., M. Dvořakova, V. Kořínek \& L. Procházkóva, 1961. Demonstration of the effect of the fish stock on the species composition of zooplankton and the intensity of metabolism of the whole plankton association. 
Verhandlungen des Internationalen Verein Limnologie Verh Int Verein Limnol 14: 192-195.

Jeppesen, E. \& P. J. Johnes, 2016. Obituary: Brian Moss (1946-2016). Hydrobiologia 778: 1-7.

Jeppesen, E., S. Brucet, L. Naselli-Flores, E. Papastergiadou, K. Stefanidis, T. Nõges, P. Nõges, J. L. Attayde, T. Zohary, J. Coppens, T. Bucak, R. F. Menezes, F. R. S. Freitas, M. Kernan, M. Søndergaard \& M. Beklioğlu, 2015. Ecological impacts of global warming and water abstraction on lakes and reservoirs due to changes in water level and salinity-. Hydrobiologia 750: 201-227.

Mamani, A., M. L. Koncurat \& M. Boveri, 2019. Combined effects of fish and macroinvertebrate predation on zooplankton in a littoral mesocosm experiment. Hydrobiologia, this issue. https://doi.org/10.1007/s10750-018-3712-y.

Mayer, T. D. \& S. L. Pilson, 2019. Interactions of water levels with water quality, endemic waterbirds, and invasive species in a shallow, tropical pond. Hydrobiologia, this issue. https://doi.org/10.1007/s10750-017-3401-2.

McCarthy, J. J., O. Canziani, N. A. Leary, D. J. Dokken \& K. S. White, 2001. Climate Change 2001: Impacts, Adaptation and Vulnerability. IPCC Working Group II. Cambridge University Press, Cambridge.

Meerhoff, M., F. Teixeira-de Mello, C. Kruk, C. Alonso, I. González-Bergonzoni, J. P. Pacheco, M. Arim, M. Beklioğlu, S. Brucet, G. Goyenola, C. Iglesias, G. Lacerot, N. Mazzeo, S. Kosten \& E. Jeppesen, 2012. Environmental warming in shallow lakes: a review of effects on community structure as evidenced from space-for-time substitution approaches. Advances in Ecological Research 46: 259-350.

Menezes, R. F., J. L. Attayde, S. Kosten, G. Lacerot, L. C. e Souza, L. S. Costa, L. S. L. da Sternberg, A. C. dos Santos,
M. M. de Rodrigues \& E. Jeppesen, 2019. Differences in food webs and trophic states of Brazilian tropical humid and semi-arid shallow lakes: implications of climate change. Hydrobiologia, this issue. https://doi.org/10.1007/ s10750-018-3626-8.

Moss, B., 2018. Ecology of Freshwaters, Earth's Bloodstream, 5 th ed. Wiley, Hoboken.

Moss, B., S. Kosten, M. Meerhoff, R. W. Battarbee, E. Jeppesen, N. Mazzeo, K. E. Havens, G. Lacerot, Z. W. Liu, L. De Meester, H. Paerl \& M. Scheffer, 2011. Allied attack: climate change and nutrient pollution. Inland Waters 1: 101-105.

Nandini, S. \& S. S. S. Sarma, 2017. The IX International Shallow Lakes Conference in Mexico: a report. SILnews 70: 11-12.

Sarma, S. S. S., M. R. Miracle, S. Nandini \& E. Vicente, 2019. Predation by Acanthocyclops americanus (Copepoda: Cyclopoida) in the hypertrophic shallow waterbody, Lake Albufera (Spain): field and laboratory observations. Hydrobiologia, this issue. https://doi.org/10.1007/s10750018-3546-7.

Sòria-Perpinyà, X., M. R. Miracle, J. Soria, J. Delegido \& E. Vicente, 2019. Remote sensing application for the study of rapid flushing to remediate eutrophication in shallow lagoons (Albufera of Valencia). Hydrobiologia, this issue. https://doi.org/10.1007/s10750-018-3741-6.

Teffera, F. E., P. Lemmens, A. Deriemaecker, J. Deckers, H. Bauer, F. W. Gamo, L. Brendonck \& L. De Meester, 2019. Why are Lake Abaya and Lake Chamo so different? A limnological comparison of two neighboring major Ethiopian Rift Valley lakes. Hydrobiologia, this issue. https://doi.org/10.1007/s10750-018-3707-8. 